\title{
Foreign Labour Employment Policy and Change in Australia, Singapore and Malaysia
}

\author{
Aster Yong \\ Victoria University, Australia
}

\begin{abstract}
Foreign nationals serving as an alternative or back-up resource of labour, whether as slaves, indentured labour or economic migrants, are by no means new or recent (Stalker 1994). Most certainly, the spread of internationalisation and the global integration of economies since the latter half of the twentieth century, have opened up many more opportunities for businesses to tap into the human resource pool of countries other than their own (Rodrik 1997).

The employment of foreigners is investigated in three countries - Australia, Singapore and Malaysia with the aim of demonstrating how each country's FLE policy had effectively operated as a value not only to control the volume but also the type of foreign labour movement into the country. In so doing, it has brought about significant changes in the employment of foreign labour as a labour resource and contributed also to the increase of international employment related migration, which is one of the important factors in global change (Castles \& Miller 2003).
\end{abstract}

\section{Introduction}

Foreign labour employment (FLE) or the practice of employing foreigners is neither new nor recent. It is however fast gaining significance as 'the new international division of labour' (Castles 1989; Findlay 1993; Kaur 2000; Papastergiadis 2000; Stalker 1994) with the employment of foreigners growing phenomenally not only within a country but also in other countries. The spread of internationalisation and the global integration of economies, particularly in the last five decades, have contributed to a rise in

(a) international employment-related migration, purported by Castles and Miller (2003) as one of the most important factors in global change.

(b) illegal employment of foreign nationals (eg. ABS 2002; DIMA 1999a; Kassim 2001a; Nayagam 1992; Pang 1993; Wong 1997).

Work practices have changed through the centuries but the employment of foreign nationals has

Copyright (C) 2006 Victoria University. This document has been published as part of the Journal of Business Systems, Governance and Ethics in both online and print formats. Educational and non-profit institutions are granted a nonexclusive licence to utilise this document in whole or in part for personal or classroom use without fee, provided that correct attribution and citation are made and this copyright statement is reproduced. Any other usage is prohibited without the express permission of the remained unequivocally essential. Early beginnings of FLE were mostly 'forced and coercive' (Stalker 1994, p. 25). Transoceanic trade and European colonialism brought about 'free and paid' employment (Castles \& Miller 2003; Kaur 2000; Papastergiadis 2000; Stalker 2000). Over time, this practice has attracted all sorts of economic migrants to the extent that for many countries today, a constant revision of visa categories has become 
necessary to accommodate the escalating demands for various types of international workers (eg. Iredale 1995, 2001; Kanapathy 2001; Kassim 2001b; Wong 1997).

FLE is a phenomenon that is affected by the interplay of a large set of variables (Yong 2005). One of them relates to the country's policy on FLE which is carried out through immigration and regulations pertaining to foreign worker employment. The aim of this paper is to demonstrate how a country's FLE policy operates like a valve not only in controlling the volume but also in the type of foreign labour movements into the country. In so doing, it significantly shapes the size and composition of a nation's population and workforce, including its basic cultural and religious foundations.

This paper will focus on three countries that share common historical beginnings as immigrant settlements (Baker 1999; Castles 1992; Chiew 1995; DIMA 2001a; Hugo 2001a; Leggett 1993; Turnbull 1980). Australia, Singapore and Malaysia were practically desolate as pre-British colonies. But time and time again, immigrant labour was brought in to populate and to develop the countries, to build them up as the nations they now are. Discussions will highlight the policies and the changes that resulted in FLE observed by Australia since WWII and by Singapore and Malaysia since their independence.

\section{Foreign Labour Employment Defined}

Deemed appropriately by Stalker (1994) as 'the work of strangers', FLE is far better understood as work carried out by non-local individuals who have come or been brought into a country for employment. These individuals can be classified as 'foreign workers within the country' and they include skilled and unskilled foreign nationals who had been either brought in by the company/recruitment agency or hired whilst they were job seeking in the country. Examples are settlers, contract workers, professionals, asylum seekers, refugees and illegal immigrants. Given labour's close association with migration, many authors such as Castles $(1987,1989)$ and Stalker $(1994,2000)$ amongst others, have tended to look upon employment of foreign nationals within the country instead as migrant labour. As a concept, foreign labour is concerned primarily with employment whereas migrant labour encompasses employment as well as settlement considerations.

FLE also takes place 'in other countries'. These individuals are effectively the 'local' workers hired within the boundaries of their own country, either for work that has been subcontracted to their company by a company from another country, or for employment in offshore 'foreign' subsidiaries and/or relocated 'foreign' companies.

\section{The Three Countries}

A country's FLE policy is closely related to the main economic activity of the country. In the early years, the main economic activity of Australia and Malaysia was in agriculture whilst that of Singapore was in commerce and trade (Chew \& Chew 1995; Drabble 2000; Peebles 2002; Turnbull 1980; Yap 2001; Year Book Australia 2005). When the countries started to industrialise manufacturing took over. More recently, these three countries are experiencing a rapid growth in the service industries. Economic restructuring resulted in numerous changes to the immigration policies and regulations concerning FLE. These in turn have made quite an impact on the nature of the foreign labour market.

\section{Australia}

In 1945, the Department of Immigration was set up to initiate a program to encourage permanent family migration (Castles 1992). This was aimed at 2 percent population growth per year, half of which was to come through immigration. It triggered a large-scale migration of workers to Australia. Between 19452001, 5.9 million immigrants came to help increase the population from 7 to 19 million (DIMA 2001b). They came from 150 countries but migrants from the British Isles remained the majority. Those from Europe, particularly Greece, Italy and Spain predominated the 1950s and 1960s years (Jupp 2001). 
When the White Australia Policy was replaced by the Policy of Multiculturalism in 1972, this caused a shift and the main immigrant intake began coming from Vietnam, Laos and Cambodia (Castles 1992; Jupp 2001).

Australia's evolution from an economy based on primary and manufacturing industries to one of service changed the focus of policies in the eighties to skilled migration (Year Book Australia 2001). Aided by the introduction of the Numerical Multifactor Assessment Scheme in 1979, policies were poised to meet shortfalls in the labour market, both in terms of filling gaps and raising the overall skill level of the Australian labour force (DIMA 2001c). In 2003-2004, 77 percent of those who were in the labour force prior to migrating were skilled with computer professionals, accountants and managers/administrators representing the top three occupations of migrants (DIMA 2005). Growing international competition for the limited pool of skilled migrants resulted in new visa categories accommodating those not intending to settle permanently in Australia (Iredale 1995, 2001). Migrants are allowed into Australia under two main programs: humanitarian and non-humanitarian.

The humanitarian program is mainly for people seeking refuge from persecution in their own country. There are three set levels in this program: Refugee Program, Special Humanitarian Program and the Special Assistance Category. From July 1997 to June 1998, 12,055 were provided with visas under the Humanitarian Program: 4,010 refugees, 4,636 Special Humanitarian and 3,409 Special Assistance (DIMA 1999b). The Department of Immigration and Multicultural and Indigenous Affairs (2003) reported that the figure of 12,000 was maintained for 2002-2003.

The non-humanitarian program consists of three main categories: Family, Skill and Special Eligibility. Within each category there are several components. The Business Skills, Employer Nominated Scheme, Distinguished Talent, Spouses and Dependent Children components are demand driven and not subject to capping. The Independent and Skilled-Australian Linked, Parents, Finances and Interdependents components, however, are subject to capping (DIMA 2003).

Under the Family Migration category, a permanent resident or citizen of Australia is permitted to sponsor their family members as potential migrants (ibid).

The Skill Migration component is designed specifically to ensure that prospective migrants possess the skills that are in demand in Australia. Entry is based on point selection criteria, which includes age, skills and English language ability. Under this scheme, prospective migrants can choose to sponsor themselves or be sponsored by relatives or employers (ibid). In 2001, links were made with the overseas students program to accommodate those seeking to migrate without having to leave Australia. This was an attempt at retaining more young, English speaking skilled migrants who have been trained in Australia (ABS 2001). According to the Department of Immigration and Multicultural and Indigenous Affairs (2003), this resulted in numbers from the Skill Stream to double that of the period 2000-2001. This scheme also includes entrepreneurs who are interested in making capital investments and distinguished individuals with unique talents that are of benefit to Australia. All information collected on the applicants is stored in The Skill Matching Database which is accessible to state and territory governments and employers for their necessary recruitments (Hugo 2001b).

The Special Eligibility category caters for former residents and citizens of Australia, New Zealanders and children born to Australian citizens overseas (ibid).

Of the three categories in the non-humanitarian program, the Skill Stream has the highest level of visas granted on record. For the period 2001-2002, there were 58 percent in the Skill Stream, 41 percent in the Family Stream and 2 percent in the Special Eligibility Stream (DIMA 2003).

Next to the United States and Canada, Australia is the third largest of the traditional countries of settlement (Stalker 1994). However, not all immigrants who come to work in Australia choose to reside permanently. The numbers of temporary working residents have been growing in recent years. They comprise working holiday makers, overseas students, and those already employed in the social/cultural (entertainers, visiting academics, sports people and religious workers), international relations (foreign government officials such as diplomats) and skilled areas (sponsored employees comprising senior 
managers, executives, specialists and technical workers). In terms of temporary working residents by occupation, the largest group (46\%) consisted of professionals (Hugo 2001c).

Migrants and temporary working residents are the two 'legal' types of foreign workers. FLE of illegals is the third type and these comprise over-stayers and unauthorised arrivals. As at 30 June 1999, there were 53,000 over-stayers in Australia. Of this number, about 27 percent had been in the country for more than nine years. China, Philippines, Fiji, Indonesia, Korea, Malaysia, Germany, United Kingdom, USA, and Japan were the ten countries with the greatest estimated number of over-stayers at this period (DIMA 1999a). There has also been an increase in the numbers of unauthorised arrivals. In 1999-2000, approximately 5,870 arrivals were apprehended for not going through the official immigration procedures, 94 percent more than the previous year. Of these, 71 percent had arrived by boat with the remainder by air. The majority who arrived by sea was Chinese and most that came by air were from Iraq (ABS 2002).

\section{Singapore}

There are three distinct phases in Singapore's foreign labour management. The first phase was regarded as Singapore's 'First Industrial Revolution' with its emphasis on obtaining cheap low-skilled labour for its growing manufacturing base (Wong 1997).

Singapore inherited a flagging economy, chronic unemployment and industrial unrest with its independence in 1965 (Pang 1988). It had little choice but to adopt an industrialisation strategy. Success with attracting foreign investments for its labour-intensive export-oriented manufacturing led to a quickening growth in the economy in the late sixties and early seventies (ibid). This brought about a severe labour shortage that resulted in an inflow of foreign workers (Low 1995). Before 1968, unskilled foreign workers were not permitted into Singapore. This policy was relaxed in the early seventies when the government realised that it could not rely entirely on its own workforce.

The Census of Population reported that in 1970 there were 72,590 (11.15 percent of total labour force) foreign workers and by 1980 the number had increased to 119,483 (11.09 percent of total labour force) (ibid). Most were non-citizens and non-residents from the traditional source country of Malaysia (Ruppert 1999). When difficulties were encountered in getting sufficient workers from Malaysia, immigration was opened to countries such as Bangladesh, India, Sri Lanka, Philippines, Thailand and Indonesia. Permits were also extended to domestic workers in an attempt to encourage the participation of women, particularly those married with marketable skills and qualifications (ibid). Approximately 25 percent of all foreigners are employed as domestic servants and these are primarily women from the Philippines, Indonesia and Sri Lanka (Ruppert 1999; Wong 1997).

The second phase, deemed the 'Second Industrial Revolution', began in 1979 when the government's development strategy shifted to high technology, high-value added industries. This led to a boom in the construction industry and an escalating growth in the foreign labour market (Leggett 1993). Two significant directions took place in terms of the FLE policies in the eighties.

In the first instance, the government began its bid to reduce dependence on the unskilled from South and South East Asia and to phase out FLE by 1986 (Leggett 1993; Ruppert 1999). Several measures were employed to restrict the use of foreign workers and limit the entry of the unskilled into Singapore.

In 1980, employers of all work permit holders, except those holding three-year work permits, were required to contribute to the foreign worker levy scheme (Hui 1998). Employers of foreign maids were, in addition, required to deposit a security bond of S\$5,000 with the Controller of Immigration and stood to forfeit this amount in the event of breach of bond conditions. In 1987, the quota enforced by the dependency ceiling system restrained the number of foreign workers an organisation could employ. Other regulations such as limiting access of the Central Provident Fund to only skilled labour and imposing tight restrictions on the personal freedoms and immigration of dependents of unskilled foreign workers were also introduced (ibid). According to Ruppert (1999), the immigration policy was also used 
to effectively reverse the inflow of foreign labour during the 1985-86 recession when 102,000 jobs were eliminated and 60,000 foreign workers were forcibly repatriated.

In the second instance, Singapore began (in 1989) to liberalise its criteria for the issue of employment passes and permanent resident status to attract Hong Kong residents in the wake of the Tiananmen Square crackdown in China (ibid). The numbers that took up permanent residency during 1989-90 increased from 13,203 to 22,875 (Chew \& Chew 1995; Low 1995). The liberalisation was touted as a necessary step towards arresting the brain drain and declining Chinese numbers in the population caused by Singaporeans emigrating to countries such as Australia, Canada and the United States. Because the Chinese comprised as much as 85 percent of those who emigrated, this caused great concern for the dwindling size of the Chinese population which was also being affected by a declining fertility rate (Chew \& Chew 1995). According to Clammer (1991), Singapore remains one of the few modernised societies in the world that has put great emphasis on ethnicity as the primary means of social classification. The ethnic composition of the population had been fairly stable in the last decade. In 2000, the Chinese were still in the majority with 77 percent, the Malays following with 14 percent, the Indians 8 percent, Eurasians and other various ethnic groups making up the remaining 1 percent of the population (World Factbook 2003).

The third phase was marked by policy liberalisation for the expansion of the foreign labour force following strong economic growth experienced during the 1990s (Wong 1997). For example, the dependency ceiling for manufacturing was increased to 45 percent and construction was given a ratio of 5:1. A two-tier levy system was also implemented in the manufacturing sector where employers had to pay $\mathrm{S} \$ 300$ a month per worker levy for up to a dependency ceiling of 35 percent and $\mathrm{S} \$ 450$ per month per worker levy for additional workers.

This resulted in a sustained and increasing growth in the non-resident population, which developed at an annual rate of 2.7 percent in 1991. By 1996, the rise to 6.5 percent per annum had outpaced the growth of the resident population and by the end of 1995, the number of foreigners totalled more than half a million or 16 percent of the population. Seventy percent of these were unskilled work permit holders (Ruppert 1999; Wong 1997).

Since 1965, the foreign labour force (within Singapore) has been managed by the Regulation of Employment Act, which specifically prohibits foreign contract workers from any form of collective representation and procedures in the event of their services being terminated (Leggett 1993). Singapore's foreign (legal) workforce is made up of two groups: immigrant labour and guest labour (Chew \& Chew 1995). Immigrant labour refers to those who are granted permanent residency. The guest labour group consists of holders of work permits and professional/employment passes.

Two forms of regulations manage foreign labour inflow: one relating to unskilled workers and the other to skilled workers. Unskilled workers come under the work permit scheme and are employed mainly in the manufacturing, construction and service sectors. Only main contractors are eligible to apply for these permits. They are issued for workers earning less than S\$2001 per month and are valid for two years (renewable up to a cumulative total of four years). They are not transferable between occupations or employers and are subject to a levy. Permit holders are repatriated when their contracts expire. They are permitted to marry Singaporeans only with consent from the Minister for Labour and generally not allowed to bring their dependents into the country. Deportation awaits female work permit holders found pregnant.

Work permits of three years are issued for those possessing either a recognised trade certificate or acceptable educational qualifications. Holders of a three-year work permit are eligible for permanent residency after they have worked for a year. They can apply for citizenship after ten years of residency (Chew \& Chew 1995; Hui 1998). In 1999, about 450,000 were permit holders, the bulk of these were unskilled and 80,000 were holders of employment passes (Yap 2001).

Skilled workers are granted employment passes which are valid for up to five years (Chew \& Chew 1995; Hui 1998). Earning a salary in excess of $S \$ 2,001$, these workers are found in managerial, 
professional or specialist positions. Unlike permit holders, pass holders can marry Singaporeans, bring in their dependents and have their children born in Singapore. In addition, they are able to obtain permanent residency and citizenship far easier than permit holders. Permanent residency is permitted for those below 50 years and their families after six months. Those with tertiary qualifications can apply for citizenship after two years permanent residence. Non-graduate permanent residents with the requisite skills and qualifications are eligible for citizenship after five years.

The presence of illegal immigrants and over-stayers became an issue in the late eighties (Wong 1997). During the period of 1986-87, the numbers caught without work permits increased from 630 to 1,403. By 1994, the numbers had grown to 9,846. This increase was largely attributed to the sizeable increases in the levy scheme, the strict dependency ceilings and restrictions associated with the work permit system. The majority of these workers was found in the construction industry and came from Malaysia, Thailand, Indonesia and India. The Immigration Act was amended in 1988 to institute stiffer penalties, including corporal punishment. In 1995, the amendments to the Employment of Foreign Workers Act extended these punitive measures to their procurers and harbourers (ibid). In 1999, new work permit cards came with enhanced security features that would make them difficult to forge (Yap 2001).

Immigrants, 'guests' and illegals are the three main types of foreign workers within Singapore. Foreign workers are also employed 'in other countries' by government-subsidised/government-linked companies (GLCs) located in Malaysia, Indonesia, China, Vietnam, India and Thailand (Low 1995; Pang 1993; Pereira 2001; Tan 1995). Faced with labour shortages and rising wage increases, Singapore launched its regionalization policy in 1991 and moved some of its labour-intensive industries to the SingaporeJohor-Riau Growth Triangle. The move might also have been necessary because with a land area of 697 square kilometres and a population density of 6,004 per square kilometre, Singapore is one of the most densely populated countries in the world with 94 percent of its population reported to be living in highrise flats or condominiums (SDS 2005; Year Book Singapore 2004).

\section{Malaysia}

The first wave of migrant labour inflow that accompanied economic restructuring took place in the 1970s (Kanapathy 2001). This gained momentum in the mid-1980s when rapid and sustained economic growth heralded the second wave. During the 1990s, the foreign worker population grew to unmanageable proportions and warranted the deployment of foreign labour management policies carried out through bilateral agreements with major labour sending countries that included regulations pertaining to the issue and conditions of work permits and employment passes.

The first bilateral agreement took place in 1984 with the signing of the Medan Agreement with Indonesia. Similar agreements took place with the Philippines, Thailand and Bangladesh. These were undertaken to negotiate for the quantity and quality (in terms of skill types) of foreign workers to be employed. By signing with selected countries, Malaysia was able to determine the nationality of foreign workers being recruited (ibid).

In July 1996, the government stopped issuing new entry permits to foreign labour in construction, services and plantations in an effort to stabilise the numbers. Following the 1997 economic crisis, Malaysia placed a total ban on the recruitment of foreign labourers except those from Indonesia and Thailand. It considered the latter act as providing necessary assistance to its immediate neighbours. Two hundred thousand foreign workers were also repatriated and over 180,000 illegal workers opted to be sent back to their home country. Since then, it has practised 'selective recruitment' (Kassim 2001b, p. 274) by permitting foreign employment in sectors regarded as critical such as plantations, manufacturing and domestic services.

In early 1998, the government increased its efforts to reduce the economy's dependency on foreign labour, particularly in the manufacturing and service sectors, by measures such as repatriation and levy. It also introduced stricter recruitment conditions, for example, annual medical examinations for foreign workers, higher income-level requirement for those wishing to employ foreign maids and restrictions of 
one foreign maid per household with children. These were effective but when labour shortages became an issue in mid-1998, the entry of 120,000 foreign workers for plantation and export-oriented manufacturing sectors were permitted and with the revival of manufacturing in 1999 , another 700,000 were allowed into Malaysia. Approximately 70 percent of these workers were located in the Kelang Valley in the Peninsula, having come mainly from Indonesia (64\%), Philippines (7\%), Bangladesh (25\%), Thailand (1\%), Pakistan (1\%) and India (3\%) (Kassim 2001a).

Since 1997, the government permitted expatriate husbands of Malaysian women to be employed under the foreign spouse program (Kanapathy 2001). Only expatriate wives of Malaysian men were allowed to seek employment previously.

The 1.6 million foreign nationals in 1999 accounted for 11.4 percent of the labour force and 11.6 percent of those employed (Far East \& Australasia 2005). By 2000, the foreigners numbered close to two million with 31 percent engaged in manufacturing, 23 percent in agriculture, 9 percent in construction, 7 percent in services while 20 percent alone were employed as maids.

The administration of rules and regulations governing the rights and obligations of foreign workers are handled separately and differently by the Immigration Department (under the Ministry of Home Affairs) and the Labour Department (under the Ministry of Human Resources) in East and West Malaysia ${ }^{23}$ (Kassim 2001a). The rights and obligations of foreign workers vary in terms of their legal status and the category of work they are engaged in. Generally, they are prohibited from joining trade unions and are not covered by collective agreements. They are only covered under the Workmen's Compensation Act of 1952 (since 1998) and the Employees Provident Fund. There is no minimum wage and employers are free to remunerate in accordance with market forces.

There are two main categories of foreign (legal) workers: expatriates (skilled personnel and professionals) and non-expatriates (labourers, both unskilled and semi-skilled). Expatriates are issued with employment passes whilst the non-expatriates are given temporary work passes.

Records on expatriates started only in mid-1997 with an estimated 12,600 workers. There was an open policy for entry by skilled workers and professionals from any country except Israel and Yugoslavia. Malaysia received expatriates from well over 100 different countries with the majority coming from the United Kingdom, Japan and India. Generally, they were found occupying top managerial and executive positions in the private sector (multinationals mostly).

Expatriates are issued with three types of employment passes. The first consists of those working for less than one year and earning a minimum monthly income of RM2,500. The second comprises those earning this income level but working for a minimum of one year. The third are issued to those earning less than RM2,500 a month. These passes are similar to those issued to non-expatriate unskilled and semi-skilled with the exception being that these pass holders are not required to pay the annual employment levy or undergo annual medical examinations. Maximum employment is permitted up to five years and all employment passes have to be renewed every year.

Temporary work passes for non-expatriates are also renewable on a yearly basis. However, these foreign workers are only permitted to work for a period of two to seven years after which they must return to their country of origin. They are allowed to re-enter after a lapse of six months. Compared to expatriates, holders of temporary work passes have fewer rights. They are not permitted to bring in their dependents, marry locals or be found pregnant in the case of women. They are also subject to annual medical examinations (ibid).

Temporary work passes had previously been issued only to Indonesia, Thailand, Philippines, Bangladesh and Pakistan (Kassim 2002). Nationals of other countries were permitted only when these types of workers were in greater demand (Kassim 2001b). Holders of temporary work passes are moreover, permitted employment only in sectors where local labour is not available (Kassim 2001a).

Geographically, Malaysia is made up of two parts: the Peninsula, known as Western Malaysia as one part, and Sabah and Sarawak on the northern quarter of Borneo island, known as East Malaysia as the other part (Milne \& Mauzy 1986). 
For example, during the 1970s and 1980s, they were allowed to work only in domestic services, plantations and construction. Since 1993, jobs were opened to them in manufacturing and other services. Another development that occurred was a greater diversification in the types of jobs available to female foreign workers. This resulted in females constituting approximately one-third of all foreign workers in manufacturing and one-half in services (Kassim 2001b). These jobs are held mainly by Filipinos and available in the Peninsula. Indonesians and Thais tend to work in plantations and construction whilst Bangladeshis are found primarily in manufacturing.

The total number of temporary work passes issued increased steadily in the 1990s (Kassim 2001a). From 533,000 in 1993, this figure increased dramatically to almost 1.5 million by 1997 . This marked increase was attributed to the massive and stringent crackdown on illegal workers in 1996.

Illegal and undocumented workers are more prevalent among foreign workers employed in agriculture, construction work and services, such as those available in restaurants, households and small-scale informal operations (Nayagam 1992; Pang 1993). To combat the large inflows during the 1970s, the government began to institute legal procedures for the recruitment and employment of foreign labourers in the 1980s. It also implemented programs such as Ops Nyah I and II in 1992 and 1996 respectively to arrest the rising numbers in the illegal entry and employment of foreigners. Between 1992 and 1999, approximately two million were apprehended. In 1998, new rules such as compound fines, imprisonment and caning were introduced. These applied not only to the illegal immigrant and worker but also to their employers and procurers and those caught falsifying official documents (Kassim 2001b).

\section{Conclusion}

From the discussions above, it is most strikingly clear that the labour market in the three countries is socially being transformed.

First and foremost, with foreign workers coming from diverse areas of origin, this has caused all three countries to experience the globalisation of migration. In Australia's early post-war years, rapid industrial growth was greatly assisted by the influx of labour from Europe but more recently, it is drawing labour from over 100 different nations, the majority of which are located in the Asian region. Malaysia has been Singapore's main source of foreign workers since its early development. Now they both serve as a magnet for workers from most countries around the globe with those from Asia predominating. This factor continues to produce a multi-racial/ethnic and multi-lingual population with a diverse range of religious beliefs and cultural heritages.

Second, the volume of foreign nationals being employed in all three countries is getting larger. Cheaper air travel and easier entry access to these countries have resulted in a significant rise in temporary migration, which accounts for a very substantial proportion of the total international flow of foreign workers. The numbers of illegal and clandestine workers have also been increasing.

This has necessitated a tightening of economic immigration regulations and national security enforcement. Immigration policies have become more regulated and selective to accommodate the everchanging requirements of various sectors in the economy. It could thus be noted that thirdly, the visa categories have grown significantly more complex in all three countries so as to cater for the many types of foreign workers. Generally, those with skill are accepted more readily whilst those with little or no skill (in Malaysia and Singapore) face restrictions in terms of access to superannuation, personal freedoms etc, even though the demands for unskilled labour remain high.

Fourth, the earlier emphasis on large numbers of low-skilled workers for the labour-intensive agriculture and manufacturing operations has obviously given way for greater expectations in the skill levels of new recruits. Industrialisation and advances made in technology have made available a greater variety of jobs and increased the number of job opportunities for women workers. Those in manufacturing and services have contributed in a major way to the foreign labour force numbers. Malaysia has one-third of 
its foreign female population in manufacturing and one-half in services. In Singapore, as much as a quarter of the total foreign labour population are employed as domestic maids.

Finally, the labour policies of each country have not been independent of themselves but were considered along with domestic politics, bilateral and regional relationships, and national security policies of nations around the world. This in itself has contributed not only to the social transformation of the labour market within each of the three countries but also to the internationalisation of FLE.

These five features correspond with the tendencies Castles and Miller (2003, p. 4-16) considered as pivotal in the next 20 years for international economic-related migration. The FLE policies of these three countries are distinct and they demonstrate their role in shaping the composition and in controlling the size and distribution of the foreign labour force which invariably impacts a nation's population and its overall economic, social and political well-being. They also point out that even though FLE might serve as an alternative labour resource for the country, it nevertheless remains a vitally important and attractive option.

\section{References}

Australian Bureau of Statistics 2001, Migration Australia, viewed 9 August 2001, http://www.abs.gov.au/ausstats/abs@.nsf.

Australian Bureau of Statistics 2002, Australia now: population - unauthorised arrivals and nonstayers, viewed 10 October 2002, http://www.abs.gov.au/ausstats/abs@.nsf.

Baker, Jim 1999, Crossroads: a popular history of Malaysia and Singapore, Times International, Singapore.

Castles, Stephen 1987, Temporary migrant workers - economic and social aspects, Occasional Paper No. 9, Centre for Multicultural Studies, University of Wollongong, NSW, Australia.

Castles, Stephen 1989, Migrant workers and the transformation of western societies, Western Societies Program, Occasional Paper No. 22, Centre for International Studies, Cornell University, Itacha, New York.

Castles, Stephen 1992, 'The 'new' migration and Australian immigration policy', in C Inglis, S Gunasekaran, G Sullivan \& CT Wu (eds.), Asians in Australia: the dynamics of migration and settlement, Allen \& Unwin, NSW, Australia, pp. 45-72.

Castles, Stephen \& Miller, Mark J 2003, The age of migration: international population movements in the modern world, 3rd edn., Macmillan Press, London.

Chew, Soon-Beng \& Chew, Rosalind 1995, 'Immigration and foreign labour in Singapore', ASEAN Economic Bulletin, vol. 12, no. 2, pp. 191-200.

Chiew, Seen-Kong 1995, 'Citizens and foreign labour in Singapore', in JH Ong, KB Chan \& SB Chew (eds.), Crossing borders: transmigration in Asia Pacific, Prentice Hall, Singapore, pp. 472-486.

Clammer, John R 1991, The sociology of Singapore religion: studies in Christianity and Chinese culture, Chopmen, Singapore.

Department of Immigration \& Multicultural \& Indigenous Affairs 1999a, Review of illegal workers in Australia: improving immigration compliance in the workplace, Commonwealth of Australia, Canberra, Australia.

Department of Immigration \& Multicultural \& Indigenous Affairs 1999b, Immigration, the facts information kit: key facts in immigration, last updated 23 July 1999, http://www.immi.gov.au/statistics/publications/index.htm.

Department of Immigration \& Multicultural \& Indigenous Affairs 2001a, Over 50 years of post-war migration, last updated 6 September 2001, http://www.immi.gov.au/statistics/publications/index.htm.

Department of Immigration \& Multicultural \& Indigenous Affairs 2001b, Key facts in immigration, last updated 7 August 2001, http://www.immi.gov.au/statistics/publications/index.htm.

Department of Immigration \& Multicultural \& Indigenous Affairs 2001c, Immigration: federation to century's end 1901-2000, last updated 13 November 2001, http://www.immi.gov.au/statistics/publications/federation/index.htm. 
Department of Immigration \& Multicultural \& Indigenous Affairs 2003, Immigration, population and citizen digest, Commonwealth of Australia, Canberra, Australia.

Department of Immigration \& Multicultural \& Indigenous Affairs, Population Issues, Population flows: immigration aspects 2003-2004 edition prepared by the Statistics Section, Business Branch, Department of Immigration, Local Government \& Ethnic Affairs, Belconnen ACT, last updated 21 January 2005, http://www.immi.gov.au/statistics/publications/popflows 2003-4/index.htm.

Drabble, John H 2000, An economic history of Malaysia, c. 1800-1990: the transition to modern economic growth, Macmillan Press, London, in association with ANU, Canberra, Australia.

Far East \& Australasia $2005,36^{\text {th }}$ edn., D Lynn (ed.), Europa Publications, London.

Findlay, Allan M 1993, 'New technology, high-level labour movements and the concept of the brain drain', in Organisation for Economic Co-operation \& Development, The changing course of international migration, France, pp. 149-159.

Hugo, Graeme 2001a, 'Population: centenary article - a century of population change in Australia', in Year Book Australia, Cat. no. 1301.0, Australian Bureau of Statistics, Canberra, pp. 169-210.

Hugo, Graeme 2001b, 'International migration and the labour market in Australia', in J Simpson (ed.), International migration in Asia: trends and policies, Organisation for Economic Cooperation \& Development Proceedings, Japan, pp. 139-175.

Hugo, Graeme 2001c, 'Foreign workers' integration in Australia and undocumented immigration in Asia', in J Simpson (ed.), International migration in Asia: trends and policies, Organisation for Economic Cooperation \& Development Proceedings, Japan, pp. 63-97.

Hui, Weng-Tat 1998, 'Labour migration in Singapore: trends and policies', in Migration and Regional Economic Integration in Asia, Organisation for Economic Cooperation \& Development Proceedings, Tokyo, pp. 155-165.

Iredale, Robyn 1995, 'Implications of skills development in APEC for Australia's migration and training policies', Department of the Parliamentary Library, Parliamentary Research Service Research Paper No. 17.

Iredale, Robyn 2001, 'Skilled migration: the rise of temporary migration and its policy implications', CAPSTRANS/CEDA Policy Papers Series 1443-4393 no. 6, University of Wollongong, NSW, Australia.

Jupp, James (ed.) 2001, The Australian people: an encyclopedia of the nation, its people and their origins, Cambridge University Press, United Kingdom.

Kanapathy, Vijayakumari 2001, 'International migration and labour market adjustments in Malaysia: the role of foreign labour management policies', Asian and Pacific Migration Journal, vol. 10, no.34, pp. 429-461.

Kassim, Azizah 2001a, 'Integration of foreign workers and illegal employment in Malaysia', in J Simpson (ed.), International migration in Asia: trends and policies, Organisation for Economic Cooperation \& Development Proceedings, Japan, pp. 113-135.

Kassim, Azizah 2001b, 'Recent trends in migration movements and policies in Malaysia', in J Simpson (ed.), International migration in Asia: trends and policies, Organisation for Economic Co-operation \& Development Proceedings, Japan, pp. 261-284.

Kassim, Azizah 2002, 'Malaysia: country studies', in Organisation for Economic Co-operation \& Development, Migration and the labour market in Asia: recent trends and policies, Japan.

Kaur, Amarjit 2000, Globalisation and the international division of labour: Southeast asian labour transformations since 1840, University of New England, New South Wales, Australia.

Leggett, Chris 1993, 'Singapore: country studies', in S Deery \& R Mitchell (eds.), Labour law \& industrial relations in Asia: eight country studies, Longman Cheshire, Melbourne, Australia, pp. 96-136.

Low, Linda 1995, 'Population movement in the Asia Pacific region: Singapore perspective', International Migration Review, vol. 29, no. 3, pp. 745-764.

Milne, Robert Stephen \& Mauzy, Diane K 1986, Malaysia: tradition, modernity and Islam, Westview Press, Boulder.

Nayagam, James 1992, 'Migrant labour absorption in Malaysia', Asian and Pacific Migration Journal, vol. 1, no. 3-4, pp. 477-494. 
Pang, Eng-Fong 1988, 'Development strategies and labour market changes in Singapore', in EF Pang (ed.), Labour market developments and structural change: the experience of ASEAN and Australia, Singapore University Press, Singapore, pp. 195-242.

Pang, Eng-Fong 1993, Regionalisation and labour flows in Pacific Asia, Development Centre of the Organisation for Economic Co-operation \& Development, Paris, France.

Papastergiadis, Nikos 2000, The turbulence of migration: globalization, deterritorialization and hybridity, Polity Press, Cambridge.

Peebles, Gavin 2002, 'Economy - Singapore', in Lynn Daniel (ed.), Far East \& Australasia, $33^{\text {rd }}$ edn., Europa Publications, London, pp. 1218-1230.

Pereira, Alexius 2001, 'Revitalizing national competitveness: the transnational aspects of Singapore's regionalisation strategy (1990-2000)', Working Paper Series, Department of Sociology, National University of Singapore.

Ruppert, Elizabeth 1999, 'Managing foreign labour in Singapore and Malaysia: are there lessons for GCC countries?', World Bank 1818 H Street, NW Washington DC 20433, Working Papers International Economics, Trade, Capital Flows No 2053, http://wbln0018.worldbank.org/research/workpapers.nsf

Singapore Department of Statistics 2005, The Census of Population 2000 handbook in pdf, viewed 6 May 2005, http://www.singstat.gov.sg.

Stalker, Peter 1994, The work of strangers: a survey of international labour migration, International Labour Office, Geneva.

Stalker, Peter 2000, Workers without frontiers: the impact of globalisation on international migration, International Labour Office/Lynne Rienner, Switzerland/Colorado.

Tan, Chwee-Huat 1995, Labour management relations in Singapore, Prentice-Hall, Singapore.

Turnbull, Mary C 1980, A short history of Malaysia, Singapore and Brunei, Graham Brash, Singapore.

Wong, Diana 1997, 'Transience and settlement: Singapore's foreign labour policy', Asian \& Pacific Migration Journal, vol. 6, no. 2, pp. 135-167.

World Factbook 2003, 'Australia' http://www.bartleby.com/151/as.html, 'Singapore', http://www.bartleby.com/151/sn.html, 'Malaysia', http://www.bartleby.com/151/my.html, last viewed 6 May 2005.

Yap, Mui-Teng 2001, 'Recent economic, labour market and migration developments in Singapore', in John Simpson (ed.), Organisation for Economic Co-operation \& Development Proceedings, International Migration in Asia: trends and policies, Japan, pp. 299-304.

Year Book Australia 2001, Labour special article - a century of change in the Australian labour market, Australian Bureau of Statistics, Canberra, Cat. no. 1301.0, pp. 213-247.

Year Book Australia 2005, no. 87, Commonwealth of Australia, Canberra, Cat. no. 1301.0.

Yearbook of Statistics, Singapore 2004, Population and land area, last updated 7 June 2004, viewed 6 May 2005, http://www.singstat.gov.sg.

Yong, Aster 2005, Managerial attitudes, ethics and foreign labour, $\mathrm{PhD}$ thesis, Victoria University, Melbourne, Australia. 
